\title{
Microbiological Evaluation of Some Edible Bovine By-products
}

\author{
A.M. Abd-El-Malek* and T. El-Khateib \\ Department of Food Hygiene (Meat Hygiene), Faculty of Veterinary Medicine, Assiut \\ University, 71515 Assiut, Egypt \\ *Corresponding author
}

\section{Keywords}

Microbiological evaluation, Edible Bovine Byproducts, Salmonella spp., E. coli 0157:H7

Article Info

Accepted: 26 December 2017 Available Online: 10 January 2018

\section{A B S T R A C T}

Microbiological evaluation of edible bovine by-products (intestine, lung, rumen meat, head flesh, heart, tongue, kidney and liver) commonly consumed in Assiut city, Egypt were determined by enumerating total viable bacterial count (TVBC), total enterobacteriacae count, yeast and mold contaminants and determine the presence of Salmonella spp. and E. coli $\mathrm{O} 157: \mathrm{H} 7$ organisms. The obtained results showed that the mean TVBC of intestine, lung, rumen meat, head flesh, heart, tongue, kidney and liver were $9 \times 10^{6}, 14 \times 10^{6}, 6 \times 10^{7}$, $8 \times 10^{7}, 7 \times 10^{6}, 9 \times 10^{6}, 7 \times 10^{6}$ and $5 \times 10^{6} \mathrm{cfu} / \mathrm{g}$, respectively. While, the mean enterobacteriacae count of intestine, lung, rumen meat, head flesh, heart, tongue, kidney and liver were $3 \times 10^{6}, 3 \times 10^{6}, 3 \times 10^{7}, 4 \times 10^{6}, 7 \times 10^{5}, 3 \times 10^{6}, 3 \times 10^{6}$ and $3 \times 10^{6} \mathrm{cfu} / \mathrm{g}$, respectively. Furthermore, the mean total fungal count of intestine, lung, rumen meat, head flesh, heart, tongue, kidney and liver were $3 \times 10^{4}, 8 \times 10^{4}, 2 \times 10^{4}, 6 \times 10^{4}, 1 \times 10^{4}, 7 \times 10^{4}$, $9 \times 10^{5}$ and $8 \times 10^{4} \mathrm{cfu} / \mathrm{g}$, respectively. Two S. enteritidis could be isolated from intestine and lung samples. One isolate of S. typhimurium was detected in intestinal sample. E. coli 157:H7 contamination was found in intestine, lung, rumen meat and head flesh, respectively. The results of this study show that edible bovine by-products are crosscontaminated by E. coli $0157: \mathrm{H} 7$, S. enteritidis and S. typhimurium and thus may pose potential risk for public health. It is recommended that hygiene improvements are needed in the establishments selling edible bovine by-products to protect public health.

\section{Introduction}

Edible meat by-products are a very economical source of high quality protein. They are rich in mineral and vitamin contents (Oztan, 2005; Seong et al., 2014). In Egypt, the continuous increase in meat price lead the consumer to search for another suitable cheaper source of protein such as edible bovine by-products (Ockerman and Hansen, 2000). Edible bovine by-products are edible parts of internal organs also called variety meat or offal such as liver, kidney, heart, tripe and lung are eaten in large quantities by the population and most popular in Egypt especially in poor places. Also, they are consumed in many countries all over the world like Turkey (Nazlı et al., 2005). Rumen meat, also, known as tripe is one of the important edible bovine by-products obtained from the first two chambers of a cattle's stomach: the rumen and the reticulum (Anna 
Anandh et al., 2012). Tripe is one of the high proteinnacious by product obtainable from slaughter house and is inexpensive with a distinguished taste (Ndeddy and Babalola, 2011). The intestine is a very long organ and is ideal for a casing of the sausage. Mumbar means stuffed intestines made by stuffing the large intestine which are short and tubby, while those made from the small intestine are long and slender. Due to readily available nutrients and poor hygienic conditions during handling, collection and processing, edible bovine by-products generally possess poor microbial quality (Selvan et al., 2007). As well as they have high loads of microorganisms (Oztan, 2005). They can be contaminated more frequently than animal carcasses by Salmonella (Little et al., 2008). Edible beef by-products have recently received significant attention worldwide (Im et al., 2016).

However, studies evaluating the microbial safety of diverse edible beef by-products and specifically investigating contamination by pathogens that cause foodborne illnesses are rare. The scarcity of the published information about the microbiological evaluation of edible bovine by-products obtained from different butcher's shops and street vendors. Therefore, this study was carried out to enumerate total viable bacterial count, total Enterobacteriacae count and total fungal contaminants and to determine the presence of Salmonella spp. and Escherichia coli $\mathrm{O} 157: \mathrm{H} 7$ in some edible bovine by-products commonly consumed in Assiut city, Egypt.

\section{Materials and Methods}

\section{Samples}

A total of 132 edible bovine by-products (included 36 intestine, 27 lung, 26 rumen meat, 11 head flesh, 6 heart, 6 tongue, ten liver and ten kidney) samples were collected randomly from different butchers open shops and street vendors in Assiut city, Egypt. Samples were collected within 3 hours postslaughter and during early morning, in order to minimize the microbial changes due to environmental temperatures and postslaughter timings.

Each sample was aseptically placed into a sterile plastic bag, labelled and transferred immediately to the laboratory for bacteriological analysis. The selected internal organs were washed under running tap water to remove adhering blood, food remnants, feces, impurities, trimmed off of visible fats and connective tissues. Rumen meat was cut into small chunks of about $2.5 \mathrm{~cm}$ (Anna Anandh et al., 2004).

\section{Microbial analysis (PHLS, 1998)}

The microbiological examinations of bovine by-products were assessed on the basis of Total Viable Bacterial Count (TVBC), total Enterobacteriacae count and total fungal count. TVBC determined on standard plate count agar (OXOID, CM0463), Enterobacteriacae cultured on MacConkey agar (Biolife, CB 5502) and total fungal detected on Malt extract agar Base (HIMEDIA, M137). The standard procedure recommended by (ISI, 1980) was followed for microbial analysis with above respective media.

All plates were incubated under aerobic conditions at $36 \pm 1^{\circ} \mathrm{C}$ for $24-72 \mathrm{hrs}$. The mean number of colonies counted was expressed as colony forming units (cfu)/ per gram. Detection and serological identification of Salmonella spp. according to Kauffman (1974) and ISO (2002). Isolation and serology of E. coli 0157:H7 as recommended by De Boer and Heuvelink (2000) and Kok et al., (1996). Data analysis was performed using SPSS v.16 statistical software package. 


\section{Results and Discussion}

\section{Total Viable Bacterial Count (TVBC)}

The obtained results demonstrated in Table 1 showed that the mean TVBC of intestine, lung, rumen, head muscles, trachea, heart, tongue, diaphragm, kidney and liver were $9 \times 10^{6}, 14 \times 10^{6}, 6 \times 10^{7}, 8 \times 10^{7}, 9 \times 10^{6}, 7 \times 10^{6}$, $9 \times 10^{6}, \quad 1 \times 10^{7}, \quad 7 \times 10^{6}$ and $5 \times 10^{6} \mathrm{cfu} / \mathrm{g}$, respectively. The achieved results revealed that the TVBC of the edible bovine offal samples were higher than the permissible limits recommended by Egyptian Standard (E S, 2005). Similarly, in a related study conducted in Benha, Egypt, the mean value of TVBC of lung, liver, kidneys and heart were $4.01 \times 10^{7}, 1.28 \times 10^{7}, 3.90 \times 10^{6}$ and $2.15 \times 10^{6}$ $\mathrm{cfu} / \mathrm{g}$, respectively (Gafer-Rasha, 2013). During slaughter and processing, all edible bovine tissues are subjected to contamination from a variety of sources within and outside animal. The contaminating organisms are derived mainly from the hide of the animal and also comprise organisms that originate from feces (Datta et al., 2012).

\section{Enterobacteriaceae count}

According to the data recorded in Table 2, the mean enterobacteriacae count of intestine, lung, rumen, head muscles, trachea, heart, tongue, diaphragm, kidney and liver were $3 \times 10^{6}, 3 \times 10^{6}, 3 \times 10^{7}, 4 \times 10^{6}, 4 \times 10^{6}, 7 \times 10^{5}$, $3 \times 10^{6}, \quad 2 \times 10^{7}, \quad 3 \times 10^{6}$ and $3 \times 10^{6} \mathrm{cfu} / \mathrm{g}$, respectively. These results revealed that the total enterobacteriacae count of the edible bovine offal samples were higher than the permissible limits sets by Egyptian Standard (E S, 2005). The achieved results in the current study revealed a higher counts of enterobacteriacae in different edible bovine offals compared with other authors such as Faten et al., (2013) who recorded that the mean values of total Enterobacteriaceae count/g of lung, liver and heart samples were
$8.53 \times 10^{4}, 3.96 \times 10^{4}$ and $9.17 \times 10^{3}$, respectively and Hafez et al., (1994) who found that Enterobacteriacae count of heart and liver was $2 \times 10^{3}$ and $4 \times 10^{4}$, respectively. Also, lower findings were reported by Ishak (1992) who found that Enterobacteriacae count $3.4 \times 10^{3}$ cfu/g in abattoir samples; El-Seiiedy (1997) who found that Enterobacteriacae count of cattle liver was $4.28 \times 10^{4}$ and Ammar et al., (2012) who recorded that Enterobacteriacae count in examined beef liver was $2.2 \times 10^{3}$. The Enterobacteriaceae family is one of the main bacterial groups implicated in the contamination of bovine tripe. Their presence in a food is an indication of improper hygienic measures (Gill and Landers, 2004).

\section{Total fungal count (TFC)}

Our results in Table 3 found that the mean total fungal count of intestine, lung, rumen, head muscles, trachea, heart, tongue, diaphragm, kidney and liver were $3 \times 10^{4}$, $8 \times 10^{4}, 2 \times 10^{4}, 6 \times 10^{4}, 12 \times 10^{4}, 1 \times 10^{4}, 7 \times 10^{4}$, $8 \times 10^{4}, 9 \times 10^{5}$ and $8 \times 10^{4} \mathrm{cfu} / \mathrm{g}$, respectively. As E S (2005) does not establish safety limits for yeast and mould, it cannot be stated whether the values obtained here $\left(1 \times 10^{4}\right.$ $8 \times 10^{4} \mathrm{cfu}$ g) imply a risk to human health. On the other hand, there are studies with higher percentages such as that carried out by GaferRasha (2013), who reported that the mean value of total mycotic counts/g of lung, liver, kidneys and heart were $1.55 \times 10^{5}, 2.97 \times 10^{5}$, $1.04 \times 10^{6}$ and $1.75 \times 10^{6} \mathrm{cfu} / \mathrm{g}$, respectively. Meanwhile, there is no fungus was found in the sample of meat and meat products except 2 samples (Datta et al., 2012). The presence of yeast /mould in the food sample is due to it's disperse in the form of spores which are abundant in the environment and can be introduce through dust and soil (Apinis, 2003). Their presence in these food samples is a serious public health concern as these fungi may be associated with the production of mycotoxin (Makun et al., 2009). 


\section{Salmonelle spp.}

Regarding Salmonella spp., the results of this study demonstrated that two $S$. enteritidis were isolated from intestine and lung (one sample from each) with percentage 3.7 and 2.7 $\%$, respectively. One strain of S. typhimurium was isolated from one intestine sample with incidence $2.7 \%$. Moreover, S. muenster (3.7\%) was isolated from one lung sample. The prevalence of Salmonella spp. in edible bovine by-products was evaluated by many investigators. In Germany Sinell et al., (1984) could isolate Salmonella with percentage of $68.9 \%$ and $28.9 \%$ in bovine lung and rumen meat samples, respectively. The recovery rates of Salmonella spp. were $10 \%$ for the liver and rumen meat samples and $20 \%$ for the brain samples obtained from local butcheries in another study conducted in Turkey Oflaz (2005). In a study performed by Akkaya et al., (2012), the detection rate of Salmonella spp. was $16 \%$ in the liver and $4 \%$ in the kidney, tripe and brain samples. Overall Salmonella prevalence $(7.1 \%)$ in cattle offal from slaughterhouses in Korea was reported by Im et al., (2016).

On the other hand, Ulutürk (1993) failed to detect salmonella in liver and rumen meat samples collected from abattoirs in Turkey. Also, Keven and Ay (2003) reported the same findings from Turkey that none of the liver, tripe and brain samples from abattoirs were found positive. The highest level of contamination of Salmonella spp. was reported from the lung samples by Sinell et al., (1984) and from the liver samples by Samuel et al., (1980).

Similarly, in our study the highest level of contamination with salmonella from intestine, lung and liver. The presence of Salmonella spp. in our samples may be due to multiple sources of contamination that crosscontamiante the offal during handling and processing post-slaughter and also reflects the intestinal bacterial load of slaughtered animals and hygienic standards of the abattoir (Akkaya et al., 2012). In addition, the sources of the Salmonella were probably the contents of the gastrointestinal tract. Furthermore, there are numerous transmission routes for Salmonellosis, but the majority of the human infections are derived from consumption of contaminated foods especially those of animal origin (Saha et al., 2016). In our study, we failed to detect salmonella in rumen meat, head flesh, trachea, heart, tongue, diaphragms and kidney. This is in accordance with the results of Selvan et al., (2007) who did not recover Salmonella from samples of retail meat products and Datta et al., (2012) who reported that none of the samples contained Salmonella and Shigella. The absence of Salmonella in these offals samples indicate the quality of raw meat and other hygienic processing including the quality of the water used in washing and cleaning. Other researchers could isolate Salmonella spp. with different percentages such as Edris et al., (2013) who could isolate S. typhimurium (4\%) from lung samples and S. typhimurium (4\%) and $S$. entertidis (4\%) from liver samples and $S$. entertidis (4\%) from kidney samples, respectively. Also, lower results were reported by Khalafalla et al., (1989) who examined 25 samples of bovine livers and could found $S$. typhimurium (4\%).

From the achieved results of the present study, it declared that $S$. enteritidis and $S$. typhimurium are the most prevalent serotypes. This result is compatible with Miller and Pegues (2005) who emphasized that $S$. typhimurium and $S$. enteritidis are the most common serotypes in the United States. Furthermore, historically, S. typhimurium is the most common agent of human food-borne disease, although in the last few decades $S$. enteritidis has become more common (Braden, 2006). 
Table.1 Total viable bacterial count (TVBC) of examined edible bovine by-products (cfu/g)

\begin{tabular}{|l|c|c|c|c|c|}
\hline Samples & No. & Min. & Max. & $X^{-}$ & SE \pm \\
\hline Intestine & 36 & $8 \times 10^{4}$ & $8 \times 10^{7}$ & $9 \times 10^{6^{*}}$ & $3.3 \times 10^{6}$ \\
\hline Lung & 27 & $1 \times 10^{5}$ & $2 \times 10^{9}$ & $14 \times 10^{6 *}$ & $9.6 \times 10^{7}$ \\
\hline Rumen meat & 26 & $9 \times 10^{4}$ & $3 \times 10^{9}$ & $6 \times 10^{7 *}$ & $1.4 \times 10^{9}$ \\
\hline Head flesh & 11 & $1 \times 10^{5}$ & $2 \times 10^{9}$ & $8 \times 10^{7 *}$ & $1 \times 10^{4}$ \\
\hline Heart & 6 & $2 \times 10^{5}$ & $5 \times 10^{6}$ & $7 \times 10^{6 *}$ & $4.8 \times 10^{5}$ \\
\hline Tongue & 6 & $2 \times 10^{4}$ & $2 \times 10^{7}$ & $9 \times 10^{6 *}$ & $2 \times 10^{6}$ \\
\hline Kidney & 10 & $1 \times 10^{7}$ & $1 \times 10^{7}$ & $7 \times 10^{6 *}$ & $7.8 \times 10^{6}$ \\
\hline Liver & 10 & $6 \times 10^{5}$ & $1 \times 10^{7}$ & $5 \times 10^{6 *}$ & $7.4 \times 10^{5}$
\end{tabular}

*Higher than Egyptian standards contamination load (ES, 2005).

Min. $=$ minimum Max. $=$ maximum $\mathrm{X}^{-}=$mean value

Table.2 Entrobacteriacae count of examined edible bovine by-products (cfu/g)

\begin{tabular}{|l|c|c|c|c|c|}
\hline Samples & No. & Min. & Max. & $\mathbf{X}^{-}$ & SE \pm \\
\hline Intestine & 36 & $5 \times 10^{4}$ & $3 \times 10^{7}$ & $3 \times 10^{6^{*}}$ & $1.2 \times 10^{6}$ \\
\hline Lung & 27 & $4 \times 10^{4}$ & $3 \times 10^{7}$ & $3 \times 10^{6^{*}}$ & $1.4 \times 10^{6}$ \\
\hline Rumen meat & 26 & $4 \times 10^{4}$ & $1 \times 10^{9}$ & $3 \times 10^{7 *}$ & $4.9 \times 10^{7}$ \\
\hline Head flesh & 11 & $2 \times 10^{4}$ & $2 \times 10^{7}$ & $4 \times 10^{6^{*}}$ & $1.5 \times 10^{6}$ \\
\hline Heart & 6 & $1 \times 10^{5}$ & $5 \times 10^{6}$ & $7 \times 10^{5 *}$ & $5 \times 10^{5}$ \\
\hline Tongue & 6 & $9 \times 10^{4}$ & $7 \times 10^{6}$ & $3 \times 10^{6^{*}}$ & $7 \times 10^{5}$ \\
\hline Kidney & 10 & $9.5 \times 10^{4}$ & $6 \times 10^{6}$ & $3 \times 10^{6^{*}}$ & $4.6 \times 10^{5}$ \\
\hline Liver & 10 & $1 \times 10^{5}$ & $5 \times 10^{6}$ & $3 \times 10^{6^{*}}$ & $3.8 \times 10^{5}$ \\
\hline
\end{tabular}

*Higher than Egyptian standards contamination load (ES, 2005).

Table.3 Total fungal count of examined edible bovine by-products (cfu/g)

\begin{tabular}{|l|c|c|c|c|c|}
\hline Samples & No. & Min. & Max. & $\mathrm{X}^{-}$ & SE \pm \\
\hline Intestine & 36 & $1 \times 10^{2}$ & $2 \times 10^{5}$ & $3 \times 10^{4}$ & $8 \times 10^{3}$ \\
\hline Lung & 27 & $6 \times 10^{3}$ & $9 \times 10^{5}$ & $8 \times 10^{4}$ & $4 \times 10^{4}$ \\
\hline Rumen meat & 26 & $1 \times 10^{2}$ & $4 \times 10^{5}$ & $2 \times 10^{4}$ & $1.9 \times 10^{4}$ \\
\hline Head flesh & 11 & $4 \times 10^{3}$ & $3 \times 10^{5}$ & $4 \times 10^{6}$ & $2.2 \times 10^{4}$ \\
\hline Heart & 6 & $3 \times 10^{3}$ & $3 \times 10^{4}$ & $1 \times 10^{4}$ & $2.7 \times 10^{3}$ \\
\hline Tongue & 6 & $2 \times 10^{4}$ & $2 \times 10^{5}$ & $7 \times 10^{4}$ & $1.8 \times 10^{4}$ \\
\hline Kidney & 10 & $6 \times 10^{3}$ & $9 \times 10^{5}$ & $8 \times 10^{4}$ & $4 \times 10^{4}$ \\
\hline Liver & 10 & $8 \times 10^{4}$ & $8 \times 10^{4}$ & $8 \times 10^{4}$ & $6.2 \times 10^{3}$ \\
\hline
\end{tabular}


Table.4 Incidence of Entrobacteriaceae in the examined samples of edible bovine by-products

\begin{tabular}{|c|c|c|c|c|c|c|c|c|c|c|c|}
\hline \multirow[t]{2}{*}{ Samples } & \multirow[t]{2}{*}{ No. } & \multicolumn{2}{|c|}{$\begin{array}{c}\text { E. coli } \\
\text { 0157:H7 }\end{array}$} & \multicolumn{2}{|c|}{$\begin{array}{c}\text { E. coli } \\
\text { 0111:H4 }\end{array}$} & \multicolumn{2}{|c|}{$\begin{array}{c}\text { Salmonella } \\
\text { spp. }\end{array}$} & \multicolumn{2}{|c|}{$\begin{array}{l}\text { Shigella } \\
\text { spp. }\end{array}$} & \multicolumn{2}{|c|}{$\begin{array}{c}\text { Providencia } \\
\text { rettgeri }\end{array}$} \\
\hline & & No. & $\%$ & No. & $\%$ & No. & $\%$ & No. & $\%$ & No. & $\%$ \\
\hline Intestine & 36 & 2 & 5.6 & - & - & 2 & 5.6 & 2 & 5.6 & 1 & 2.8 \\
\hline Lung & 27 & 4 & 14.8 & - & - & 2 & 7.4 & 4 & 14.8 & - & - \\
\hline Rumen meat & 26 & 3 & 11.5 & 1 & 3.8 & - & - & 7 & 26.9 & - & - \\
\hline Head flesh & 11 & 1 & 9.09 & - & - & - & - & 2 & 18.8 & - & - \\
\hline Heart & 6 & - & - & - & - & - & - & 1 & 16.6 & - & - \\
\hline Tongue & 6 & - & - & - & - & - & - & - & - & - & - \\
\hline Kidney & 10 & - & - & - & - & - & - & 1 & 10 & - & - \\
\hline Liver & 10 & - & - & - & - & 1 & 10 & - & - & - & - \\
\hline Total & 132 & 10 & 7.57 & 1 & 0.75 & 5 & 3.78 & 17 & 12.8 & 1 & 0.75 \\
\hline
\end{tabular}

The stomach of a cow is home to millions of microbes and therefore contamination of tripe derived from the rumen and reticulum is difficult to avoid especially during the evisceration process (Bensink et al., 2002; Ndeddy and Babalola, 2011).

\section{E. coli 0157:H7}

Concerning E. coli, in the current study $E$. coli $0157: \mathrm{H} 7$ could be isolated from intestine $(5.6 \%)$, lung $(14.8 \%)$, rumen meat $(11.5 \%)$ and head flesh $(9.09 \%)$ samples, respectively. In a related study, Asakura et al., (2012) screened 229 bovine offal products for the presence of Shiga toxin (stx) gene and found that eight $(3.5 \%)$ were positive for $E$. coli 0157:H7. Also, E. coli O157:H7 was isolated from 4 tongues $(6.7 \%), 1$ liver $(1.7 \%), 3$ omasa (5.0\%) (Asakura et al., 2014). On the other hand, lower incidence (4.9\%) of E. coli $\mathrm{O} 157: \mathrm{H} 7$ in the rumen meat were recorded by Walker et al., (2010). In the present study, rumen meat was found contaminated with $E$. coli O111:H4 serovers (3.8\%). Nearly similar results obtained by Braden (2006) who could detect E. coli O111:H4 serovers (EHEC) in lung samples $(4 \%)$ and heart samples $(4 \%)$, respectively and Bensink et al., (2002) who isolated E. coli from 25 samples of cattle livers. The isolated E. coli is serotyped as O111, O128 and O26. Higher incidence achieved by Hassan and Osaman (2008) who could determine E. coli O111 serovers (EHEC) in lung samples with percentage of $8 \%$.

\section{Shigella}

Regarding Shigella data outlined in Table 4 showed that Shigella can be found in intestine, lung, rumen meat, head flesh, heart and kidney samples with an incidence of 5.6, $14.8,26.9,18.18,16.6$ and 10\%, respectively. The presence of Shigella usually indicates improper sanitary conditions and poor personal hygiene and is principally a disease shigellosis - of humans, as well as other primates (Asghar et al., 2002).

\section{Providencia rettgeri}

Concerning Providencia rettgeri, the findings presented in Table 4 revealed that Providencia rettgeri were isolated from only one out of 36 examined intestinal samples with an incidence of $2.8 \%$. The genus Providencia, belonging to the family Enterobacteriaceae, consists of 9 spp., among these, $P$. rettgeri may be associated with 
diarrhea (Yoh et al., 2005). Shima et al., (2016) could isolate $P$. rettgeri in $2(8 \%)$ from retail meats in Thailand indicating that food animals, in particular meats, might be source of Providencia infection to human. Control measures as prevention of contamination of abattoir environment by bacteria, application of ante-mortem and post-mortem inspection in abattoirs and implementation of proper hygienic conditions by personnel working in meat industry and cleaning/disinfection of the equipments and machines used for processing are important to minimize infections caused by these pathogenic microorganisms (Akkaya et al., 2015).

The results obtained in the present study showed that the TVBC, total enterobacteriacae count of the edible bovine offal samples were higher than the permissible limits recommended by Egyptian Standards (ES, 2005). The prevalence of $E$. coli $0157: \mathrm{H7}$ in the edible beef by-products is relatively high and the most common Salmonella serotypes were S. enteritidis and $S$. typhimurium so the presence of such food poisoning microorganisms may pose potential risk for public health. It is recommended that edible bovine by-products should be separated from the viscera at evisceration process. Moreover, hygiene improvements are needed in the establishments selling edible beef byproducts to protect public health.

\section{References}

Akkaya, L., Atabay, H. I., Gök, V. and Yaman, H. 2012. Prevalence of Salmonella in edible offal in Afyonkarahisar Province, Turkey. Kafkas Üniversitesi Veteriner Fakültesi Dergisi. 18, 613-616.

Ammar, S. A., Ibrahim, A. A. Nossair, M. A. and Samaha, I. A. 2012. Microbial quality of beef liver and kidneys in Kafr - El Sheikh Province. 6th conference of
Faculty of Veternary Medicine, Alexandria 2012 Research no.41.

Anna Anandh, M., Lakshmanan, V., Anjaneyulu A. S. R. and Mendiratta, S. K. 2004. Effect of chemical treatment on deodorization and quality of buffalo rumen meat. Meat Science. 2, 25- 29.

Anna Anandh, M., Richard Jagatheesan, P. N., Rajarajan, G., Senthil Kumar, P., Paramasivam, A. and Lakshmanan, V. 2012. Quality and acceptability of traditional styled fried tripe products from buffalo and goat rumen meat. International Food Research Journal. 19, 807-810.

Apinis, A. E. 2003. Mycological aspects of stored grain. bio-deterioration of materials applied science. Publishers London. 2, 493-498.

Asakura H., Masuda, K., Yamamoto, S. and Igimi, S. 2014. Molecular approach for tracing dissemination routes of Shiga toxin-producing Escherichia coli $\mathrm{O} 157$ in bovine offal at slaughter. Biomed Research International, doi: 10.1155/2014/739139.

Asakura, H., Saito, E., Momose, Y., Ekawa, T., Sawada, M., Yamamoto, A., Hasegawa, A., Iwahori, J., Tsutsui, T., Osaka, K., Matsushita, T., Kakinuma, M., Motoyama, K., Hayama, Y., Kitamoto, H., Igimi, S and Kasuga F. 2012. Prevalence and growth kinetics of Shiga toxin-producing Escherichia coli (STEC) in bovine offal products in Japan. Epidemiology Infect. 140, 65564.

Asghar, U., Abdus, N. Samad, A. and Qazilbash, A. 2002. Identification, characterization and antibiotic susceptibility of Salmonella and Shigella species isolated from blood and stool samples of patients visiting N. I. $\mathrm{H}$, Islamabad. Journal of Medical Science. 2, 85-88.

Bensink, J. C., Dobrenov, B., Mulenga, M. P., 
Bensink, Z. S. and McKee, J. J. 2002. The microbiological quality of beef tripe using different processing techniques. Meat Science. 62, 85-92.

Braden, C. R. 2006. Salmonella enterica Serotype Enteritidis and Eggs: A National Epidemic in the United States. Clinical Infectious Diseases: an official publication of the Infectious Diseases Society of America. 43, 512-517.

Datta, S., Akter, A., Shah, I. G., Fatema, K Islam, T. H. Bandyopadhyay, A. Khan, Z. U. M. and Biswas, D. 2012. Microbiological quality assessment of raw meat and meat products, and antibiotic susceptibility of isolated Staphylococcus aureus. Agriculture, Food and Analytical Bacteriology 2(3): 188-194.

De Boer, E. and Heuvelink, A. E. 2000. Methods for the detection and isolation of STEC. Journal of Applied Microbiological Symposium supplement. 88, 133-143.

Edris, A. M., Ibrahim, H. M. and Gafer, R. W. 2013. Studies on E. coli and salmonellae in some edible offal of bovine carcasses. Benha Veterinary Medical Journal. 25, 276-283.

El-Seiiedy, N. I. 1997. Some microbial studies of cattle and camel livers. Master Degree of Vetrinary Science. Thesis (Meat Hygiene), Faculty of Veterinary Medicine. (Moshtohor), Zagazig Univ. Egypt.

ES (Egyptian Standards) 2005. Egyptian Organization for standardization and Quality control, 2062-2005.

Faten, S. H., Amani, M. S. Mervat S. H. and Gaafar, M. H. 2013. Enterobacteriacea in edible offal. Benha Veterinary Medical Journal. 25, 77-87.

Gafer-Rasha, W. M. 2013. Microbial evaluation of some edible offal in bovine carcasses. Master Degree of Veterinary Science, Benha University,
Egypt.

Gill, C. O. and Landers, C. 2004. Proximate sources of bacteria on boneless loins prepared from routinely processed and detained carcasses at a pork packing plant. International Journal of Food Microbiology. 97, 171-178.

Hafez, A. E., El-Atabany, A. E. El. Kelish H. I. and Saleh, E. 1994. Occurrence and public health importance of some microorganisms in edible offal. Alexenderia Journal of Veterinary Science. 10, 121-126.

Hassan, M.K. and Osaman, M. 2008. Microbiological status of bovine lung tissues in retailed local markets. Egyptain Journal of Comparative Pathology and Clinical Pathology. 21, 229-239.

Im, M. C., Seo, K. W., Bae, D. H. and Lee, Y. J. 2016. Bacterial quality and prevalence of foodborne pathogens in edible offal from slaughterhouses in Korea. Journal of Food Protection. 79, 163-8.

Ishak, F.B. 1992. Sanitary status of cattle livers in sharkia province. M.V.Sc (Meat Hygiene), Faculty of Veterinary Medicine, Zagazig University, Egypt.

ISI 1980. Hand book of Food Analysis, General methods. SP: 18 (Part-I) Printograph Press, Karol Bagh, New Delhi. pp: 7-18.

ISO "International Organization for Standardization" 6579-2002. 2002. (E) 4th Ed. Microbiology- General Guidance on Methods for the detection of Salmonella, International Organization for Standardization, Geneve, Switzerland.

Kauffman, G. 1974. Kauffmann white scheme. Journal of Acta Pathological Microbiological Science. 61, 385.

Keven, F. and Ay, S. 2003. Çiğ ve pişmiş sakatatta Salmonella kontaminasyonu. İnfeksiyon Dergisi. 17, 163-166. 
Khalafalla, A. F., Ibrahim, A. and ELDaly, E. 1989. Enterobacteriacae in edible offals. Alexandria Journal of Veterinary Sciences. 5, 287-295.

Kok, T., Worswich, D. and Gowans, E. 1996. Some serological techniques for microbial and viral infections. In: Practical Medical Microbiology, Collee, J., A. Fraser, B. Marmion and A., Simmons, (Eds.), 14th Edn., Edinburgh, Churchill Livingstone, UK.

Little, C. L., Richardson, J. F., Owen, R. J., Pinna, E. De. and Threlfall, E. J. 2008. Campylobacter and Salmonella in raw red meats in the United Kindom: Prevalence, characterization and antimicrobial resistance pattern, 20032005. Food Microbiology. 25, 538-543.

Makun, H. A., Gbodi, T. A., Akanya, O.H., Salako, A. E. and Ogbadu, G.H. 2009. Health implications of toxigenic fungi found in two Nigerian staples: guinea corn and rice. African Journal of Food Science. 3, 250-256.

Miller, S. and Pegues, D. 2005. Salmonella Species, Including Salmonella Typhi," in Mandell, Douglas, and Bennett's Principles and practice of infectious diseases, Sixth Edition, Chap. 220, pp. 2636-650.

Nazlı, B., H. Çolak and Hampıkyan, H. 2005. İstanbul piyasasında satışa sunulan sakatatlarda bazı anabolizan kalıntılarının mevcudiyeti üzerine bir çalışma. Istanbul üniveristesi veteriner fakültesi dergisi. 31, 83-92.

Ndeddy, A. R. J. and Babalola, O. O. 2011. Bacterial community associated with bovine tripe sold in Mafikeng Municipality, South Africa. African Journal of Microbiological Research. 5, 1532-1538.

Ockerman, H. W. and Hansen, C. L. 2000. Animal by product processing and utilization, 1st Ed., Lancaster, PA: Technomic.
Oflaz, M. 2005. Çiğ ve pişmiş sakatatta Salmonella görülme sıklığı. Yüksek LisansTezi, Cumhuriyet Üniv. Sağlık Bil. Enst.

Oztan, A. 2005. Et Bilimi ve Teknolojisi, MMOB-G1da Mühendisleri Odası Yayınları, Ankara.

PHLS (Public Health Laboratory Service), 1998. Methods for Food Products Aerobic Plate Count at 30 Deg: Surface Plate Method. Standard Method F10.

Saha, M., Debnath, C. Biswas, M. K. Pramanik, A. K. and Murmu, D. 2016. Studies on the prevalence of Salmonella spp. in meat shop premises intended to sale meat for human consumption in North Kolkata, India. International Journal of Current Microbiology and Applied Sciences. 5(4): 297-302.

Samuel, J. L., O’Boyle, A. D., Mathers, J. W. and Frost, A. J. 1980. The Contamination with Salmonella of bovine livers in an Abattoir. Australian Veterinary Journal, 56: 526-528.

Selvan, P., Mendiratta, S. K., Porteen, K. and Bhilegaonkar, K. N. 2007. Effect of trisodium phosphate on quality of Buffalo offals. American Journal of Food Technology. 2, 397.

Selvan, P., Narendra, B.R., Sureshkumar, S. and Venkataramanujam, V. 2007. Microbial quality of retail meat products available in Chennai City. American Journal of Food Technology. 2, 55-59.

Seong, P. N. , Kang, G. H., Park, K. M., Cho, S. H., Kang, S. M., Park, B. Y., Moon, S. S. and Ba, H. V. 2014. Characterization of Hanwoo bovine byproducts by means of yield, physicochemical and nutritional compositions. Korean Journal of Food Science Animal Resources. 34(4): 434447.

Shima, A., Hinenoya, A., Samosornsuk, W., Samosornsuk, S., Mungkornkaew, N., 
Yamasaki, S. 2016. Prevalence of Providencia strains among patients with diarrhea and retail meats in Thailand. Japanese Journal of Infectious Diseases. 69, 323-325.

Sinell, H.J., Klingbell and Benner, M. 1984. Microflora of edible offal with particular reference to Salmonella. Journal of Food Protection. 47, 481484.

Ulutürk, O., 1993. Ankara piyasasında tüketime sunulan sakatatın Salmonella kontaminasyonu yönünden incelenmesi.
Yüksek Lisans Tezi, Ankara Üniv. Sağlik Bil. Enst.

Walker, C., Shi, X., Sanderson, M., Sargeant, J. and Nagaraja, T.G. 2010. Prevalence of Escherichia coli O157:H7 in gut contents of beef cattle at slaughter. Foodborne Pathogen Disease. 7, 249-55.

Yoh, M., J., Matsuyama and Ohnishi, M. et al., 2005. Importance of Providencia species as a major cause of travellers' diarrhoea. Journal of Medical Microbiology. 54, 1077-82.

\section{How to cite this article:}

Abd-El-Malek, A.M. and El-Khateib, T. 2018. Microbiological Evaluation of Some Edible Bovine By-products. Int.J.Curr.Microbiol.App.Sci. 7(01): 3449-3458.

doi: https://doi.org/10.20546/ijcmas.2018.701.406 